\title{
IMPLEMENTASI DEMPSTER SHAFER UNTUK MENDIAGNOSA GANGGUAN KEHAMILAN PADA IBU
}

\author{
${ }^{I}$ Sita Muharni, ${ }^{2}$ Sigit Andriyanto, ${ }^{3}$ David Naista \\ ${ }^{1,2}$ Program Studi Sistem Informasi, STMIK Dharma Wacana \\ Jalan Kenanga No. 3 Mulyojati Metro Barat \\ ${ }^{3}$ Magister Teknik Informatika, IIB Darmajaya \\ Jalan Zainal Abidin Pagaralam No. 93 Gedong Meneng Bandar Lampung \\ e-mail : sitamuharni@dharmawacana.ac.id ${ }^{l}$, sigitandriyanto@dharmawacana.ac.id ${ }^{2}$, \\ davidnaista@gmail.com ${ }^{3}$
}

\begin{abstract}
Pregnancy is a moment where a mother carries a baby for nine months in a normal mother's pregnancy. The death rate for pregnant women is very high in Metro City, among others, the existence of diseases suffered by pregnant women namely Ectopic, Hydatidiform, Postterm, Placenta Previa, and Solutio Placenta. Due to the lack of knowledge and the high cost of consulting an obstetrician, this study tries to apply the Dempster Shafer method to the symptom data provided by an obstetrician. The system development used in this research uses RAD (Rapid Application Development). Furthermore, applying two users into a website-based system, as well as an expert system for diagnosing disorders of pregnant women with a percentage level of an expert system of $86,9 \%$.
\end{abstract}

\section{Keywords - Dempster Shafer, Pregnancy, Rapid Aplication Development}

\begin{abstract}
ABSTRAK
Kehamilan merupakan suatu moment dimana seorang ibu mengandung buah hati selama sembilan bulan pada normal kehamilan ibu. Tingkat kematian pada ibu hamil sangat tinggi di Kota Metro antara lain, adanya penyakit yang diderita oleh ibu hamil yakni Ektopik, Hidatidosa, Postterm, Plasenta Previa, dan Solutio Plasenta. Kurangnya pengetahuan dan mahalnya biaya konsultasi kepada dokter spesialis kandungan, maka penelitian ini berusaha mengaplikasikan metode dempster shafer kedalam data gejala yang diberikan oleh dokter spesialis kandungan. Pengembangan sistem yang digunakan pada penelitian ini menggunakan RAD (Rapid Aplication Development). Selanjutnya menerapkan dua user kedalam sistem berbasis website, serta sistem pakar diagnosa gangguan ibu hamil dengan tingkat presentase sistem pakar sebesar 86,9\%.
\end{abstract}

\section{Kata Kunci --- Dempster Shafer, Kehamilan, Rapid Aplication Development}

\section{Pendahuluan}

Menurut International Federation of

Obstetrics and Gynecology, kehamilan

didefinisikan sebagai pembuahan atau pengikatan sel sperma dan sel telur, diikuti dengan nidasi atau implantasi [1] . Dari pembuahan hingga kelahiran bayi, menurut kalender internasional, kehamilan normal terjadi dalam waktu 40 minggu atau 10 atau 9 bulan. 
Kehamilan dibagi menjadi tiga semester, semester pertama 12 minggu, semester kedua 15 minggu (13-27 minggu), dan semester ketiga 13 minggu (28-40 minggu) [2].

Banyak hal yang mempengaruhi tingginya angka kematian ibu hamil di Indonesia. Misalnya, kurangnya pengetahuan tentang cara menjaga kesehatan ibu hamil, kurangnya pengetahuan tentang penyakit yang sering diderita ibu hamil, fasilitas kesehatan yang tidak memadai, dan kurangnya dokter/bidan yang dapat mengobati penyakit ibu. [3]. Namun, dengan adanya dokter spesialis dan bidan, mungkin terdapat kelemahan seperti batasan jam kerja yang sebenarnya dan banyaknya pasien yang harus mengantri. [4]. Dalam hal ini, ibu hamil sebagai pengguna jasa membutuhkan tenaga ahli yang dapat memfasilitasi diagnosis dini penyakit dan mencegahnya sejak dini. Oleh karena itu diperlukan suatu alat berupa sistem pakar yang dapat mendiagnosa penyakit pada ibu hamil.

Pada penelitian terdahulu, diagnosa yang pernah dilakukan adalah menggunakan metode forward chaining. Hasil diagnosis sistem menggunakan metode forward chaining pada gangguan kehamilan menunjukkan bahwa hasil diagnosis yang dialami pasien menunjukkan sesuai dengan yang telah didiagnosis oleh dokter atau spesialis [1].

Metode yang digunakan pada penelitian ini adalah Dempster Shafer. Metode Dempster Shafer adalah metode ketidakpastian untuk menghasilkan diagnosis yang akurat. Karena penambahan atau pengurangan fakta baru dalam bentuk informasi tentang gejala dan gangguan [5]. Metode Dempster Shafer ini digunakan untuk menentukan gangguan yang sedang dialami oleh ibu hamil, sebelumnya akan dimulai dengan proses pertanyaan (fakta-fakta) dengan gejalagejala yang akan menyeleksi solusi terbaik dari sejumlah solusi, dalam hal ini solusi yang dimaksud adalah ganguan kehamilan yang dibutuhkan oleh wanita yang sedang hamil berdasarkan faktor yang ditentukan. Dengan metode sistem pakar tersebut, diharapkan memberikan solusi karena didasarkan pada pertanyaan (fakta-fakta) gejala-gejala ganguan kehamilan yang sudah ditentukan sehingga akan mendapatkan hasil yang akurat terhadap bagaimana proses mendiagnosa ganguan kehamilan [6]. Adapun masalah yang dapat dirumuskan yang nantinya akan mencocokan fakta-fakta, solusinya yaitu bagaimana merancang sebuah sistem pakar dengan menggunakan Metode Dempster Shafer untuk menentukan kepakaran proses ganguan kehamilan serta 
bagaimana penerapan metode Dempster Shafer untuk membantu dalam pengambilan kepakaran proses dalam ganguan kehamilan berbasis web.

\section{Metode Penelitian}

Metode penelitian yang akan digunakan dalam penelitian ini meliputi dua bagian yaitu metode pengumpulan data dan metode pengembangan perangkat lunak.

\section{1. Metode Pengumpulan Data}

Metode pengumpulan data yang digunakan pada penelitian ini adalah:

a. Observasi

Dalam metode ini dilakukan penelitian dan pengamatan secara langsung pada Rumah bersalin dr. Ellysawati Shinta,SPoG yang praktik di RSIA AMC J1 Kunang No.15 Kecamatan Metro Pusat Kota Metro Lampung 34111. Peneliti melakukan pengamatan mengenai proses mediagnosa ganguan kehamilan yang sering terjadi pada ibu hamil.

b. Wawancara

Pada tahap ini dilakukan pengumpulan fakta-fakta yang mendukung perancangan sistem dengan mengadakan konsultasi dengan seorang pakar yang bernama dr. Ellysawati Shinta, SPoG selaku dokter kandungan RSIA AMC Metro dan membandingan dengan yang ada pada buku penuntun.

c. Studi Pustaka

Pada metode ini, peneliti mengumpulkan data dari buku, artikel ilmiah dan internet yang berhubungan dengan masalah yang dibahas pada penelitian ini.

\section{2. Metode Pengembangan Sistem}

Dalam penelitian menggunakan model RAD (Rapid Aplication Development) bertujuan mempersingkat waktu yang biasanya diperlukan dalam siklus hidup pengembangan sistem tradisional antara perancangan dan penerapan suatu sistem informasi [4]. Berikut ini adalah tahaptahap pengembangan aplikasi dari tiap-tiap fase pengembangan sistem yaitu:

\section{A. Requirements \\ Planning \\ (Perencanaan Syarat - Syarat)}

1) Mengidentifikasi Tujuan Aplikasi

Tujuan dari perancangan ini adalah membuat suatu aplikasi berbasis web tentang sistem mediagnosa gangguan kehamilan. Dengan munculnya gangguan kehamilan yang dapat dialami oleh ibu hamil, serta kurangnya tenaga ahli di rumah bersalin yang dapat mediagnosa gangguan kehamilan berdasarkan gejala gangguan kehamilan, maka diperlukan suatu langkah yang tepat untuk mengetahui jenis gangguan kehamilan dialami oleh 
ibu hamil berdasarkan gejala-gejala yang terjadi secara tepat dan cepat. Pemanfataan teknologi komputer dapat digunakan untuk membantu pengguna untuk mendiagnosa jenis gangguan kehamilan berdasarkan gejala-gejala gangguan kehamilan yang ada di metro dr. Ellysawati Shiinta, SPoG.

2) Syarat-Syarat Membangun Aplikasi Syarat - syarat untuk mencapai tujuan dalam pengembangan aplikasi berbasis web tentang sistem mendiagnosa gangguan kehamilan, meliputi hal - hal sebagai berikut :

a) Bahasa pemograman PHP

b) Database Management System (DBMS) MySQL

c) Web Apache

d) Web Browser

e) Sistem pakar (menggunakan metode Dempster Shafer)

3) Analisis dan Kebutuhan

Untuk mempermudah melakukan analisis kebutuhan maka diperlukan pengelompokan kebutuhan yaitu:

a. Kebutuhan Fungsioanal

1) Mampu menganalisis permasalahan tentang gangguan kehamilan yang ada pada ibu hamil sekitar daerah metro.

2) Melakukan diagnosa jenis gangguan

kehamilan berdasarkan gejala-gejala yang ditimbulkan yang pada ibu hamil.

3) Menerapkan cara dan solusi dari hasil diagnosa gangguan kehamilan yang ada pada ibu hamil.

4) Dapat digunakan oleh ibu hamil daerah sekitar metro sebagai identifikasi tentang gangguan kehamilan ibu hamil. terutama pada gejalagejala yang timbul [7]. Sedangkan Operator dr. Ellysawati Shinta,SPoG yang bertugas memberikan jawaban sesuai rule yang ada di sistem, ibu hamil mempunyai hak akses sebagai pengguna yang melakukan konsultasi tentang gangguan kehamilan yang ada pada ibu hamil, dan dapat melihat hasil perhitungan pakar diagnosa gangguan kehamilan.

b. Kebutuhan Non Fungsional

1. Analisis Kebutuhan Perangkat Lunak

Analisis perangkat lunak terdiri dari spesifikasi minimum 
perangkat lunak yang dipakai

dalam membangun dan mengimplementasikan sistem diagnosa gangguan kehamilan, yaitu :

a) Sistem Operasi Windows

b) Web Browser

c) Database Management System (DBSM) MySQL

d) Web Server Apache

2. Analisis Kebutuhan Perangkat Keras. Berikut ini adalah spesifikasi perangkat keras minimum yang mendukung sistem diagnosa gangguan kehamilan rumah bersalin ganjar asri metro, yaitu:

Processor :

Kapasitas

Minimum 2.0 GHZ

Memori : Minimum 2 GB

3. Analisis Kebutuhan Pengguna (User)

Pada tahap analisis sistem pengguna yang berkaitan secara langsung dengan permasalahan tentang diagnosa gangguan kehamilan pada ibu diantaranya yaitu:

a. Operator mempunyai kewenangan penuh terhadap sistem. Sistem pakar diagnosa gangguan kehamilan pada ibu hamil dapat melihat dan mengubah semua data sistem, dan dapat memperbaiki aturan kesalahan yang terjadi dalam sistem. Operator yang akan mengolah data diagnosa gangguan kehamilan pada ibu hamil menggunakan metode Dempster Shafer. Operator juga yang memasukkan data basis pengetahuan gangguan kehamilan pada ibu hamil dan gejala serta penilaian sehingga sesuai dengan aturan metode Dempster Shafer. Operator dapat menambah, mengurangi, melihat riwayat konsultasi yang ada.

b. User merupakan seluruh ibu hamil pengguna sistem, mempunyai kewenangan melihat hasil diagnosa tentang penyakit gangguan kehamilan dengan melakukan konsultasi dan mendapatkan solusi dari penerapan metode Dempster Shafer.

4. Rule (Aturan)

$\mathbf{R 1}$ = IF Nyeri pada puncak bahu dan sisi leher AND Pendaharahan sedikit warna coklat gelap AND Penurunan tekanan darah dan kenaikan denyut nadi AND Suhu tubuh meningkat $38^{\circ} \mathrm{C}$ THEN P01 | Kehamilan ektopik 
R2 = IF Pendaharahan merupakan gejala utama AND Mual muntah seperti kehamilan biasa hanya derajat keluhan lebih dari yang biasa AND Perkembangan kehamilan lebih pesat dari kehamilan biasa THEN P02 |Kehamilan Hidatidosa

$\mathbf{R 3}=$ IF Air ketuban yang kurang AND Gerakan janin yang jarang THEN P03 |Kehamilan Post term

R4 = IF Pendarahan tanpa alasan atau tanpa rasa nyeri. AND Pendarahan dapat terjadi selagi penderita tidur atau bekerja biasa THEN P04 |Plasenta Previa

R5 = IF Pendarahan dan shok AND Sakit perut terus menerus AND Uterus terasa tegang terus menerus AND Detak jantung janin tidak terdengar lagi THEN P05 |Solutio Plasenta

\section{Nama Gejala}

Nama gejala gangguan kehamilan pada ibu dijelaskan pasa Tabel 1 .

Tabel 1. Nama Gejala

\begin{tabular}{|c|l|c|}
\hline $\begin{array}{c}\text { Kode } \\
\text { Gejala }\end{array}$ & $\begin{array}{c}\text { Nama Gejala } \\
\text { densitas }\end{array}$ \\
\hline G1 & $\begin{array}{l}\text { Nyeri pada puncak } \\
\text { bahu dan sisi leher }\end{array}$ & 0,72 \\
\hline G2 & $\begin{array}{l}\text { Pendaharahan pada } \\
\text { vagina sedikit warna } \\
\text { coklat gelap }\end{array}$ & 0,60 \\
\hline G3 & $\begin{array}{l}\text { Kepala pusing kunang- } \\
\text { kunang dan denyut } \\
\text { nadi meningkat }\end{array}$ & 0,53 \\
\hline
\end{tabular}

\begin{tabular}{|c|c|c|}
\hline G4 & $\begin{array}{l}\text { Suhu tubuh panas } \\
\text { meningkat } 38^{\circ} \mathrm{C}\end{array}$ & 0,83 \\
\hline G5 & $\begin{array}{l}\text { Pendarahan } \\
\text { merupakan gejala } \\
\text { utama }\end{array}$ & 0,74 \\
\hline G6 & $\begin{array}{l}\text { Mual muntah seperti } \\
\text { kehamilan semester } \\
\geq 1 \text { dengan semester } \\
\leq 6 \text { biasa hanya derajat } \\
\text { keluhan lebih dari } \\
\text { yang biasa }\end{array}$ & 0,62 \\
\hline G7 & $\begin{array}{l}\text { Perkembangan } \\
\text { kehamilan semester } \\
\geq 6 \text { lebih pesat dari } \\
\text { kehamilan biasa }\end{array}$ & 0,83 \\
\hline G8 & $\begin{array}{l}\text { Pendarahan tanpa } \\
\text { alasan atau tanpa rasa } \\
\text { nyeri. }\end{array}$ & 0,75 \\
\hline G9 & $\begin{array}{l}\text { Pendarahan dapat } \\
\text { terjadi selagi penderita } \\
\text { tidur atau bekerja biasa }\end{array}$ & 0,85 \\
\hline G10 & $\begin{array}{l}\text { Terjadi pembukaan } \\
\text { saluran air ketuban }\end{array}$ & 0,78 \\
\hline G11 & $\begin{array}{l}\text { Gerakan janin yang } \\
\text { jarang }\end{array}$ & 0,81 \\
\hline G12 & $\begin{array}{l}\text { Sakit perut terus } \\
\text { menerus }\end{array}$ & 0,80 \\
\hline G13 & $\begin{array}{l}\text { Otot pada kandung } \\
\text { kemihg anda terasa } \\
\text { tegang }\end{array}$ & 0,65 \\
\hline G14 & $\begin{array}{l}\text { Detak jantung janin } \\
\text { tidak terdengar lagi }\end{array}$ & 0,70 \\
\hline G15 & Pendarahan dan shok & 0,40 \\
\hline
\end{tabular}

6. Nama Penyakit

Nama penyakit yang biasa dialami oleh ibu hamil dapat dilihat pada Tabel 2. 
Tabel 2. Nama Penyakit

\begin{tabular}{|c|l|}
\hline $\begin{array}{l}\text { Kode } \\
\text { Penyakit }\end{array}$ & Nama Penyakit \\
\hline P01 & Kehamilan Ektopik \\
\hline P02 & Kehamilan Hidatidosa \\
\hline P03 & Kehamilan Post term \\
\hline P04 & Plasenta Previa \\
\hline P05 & Solutio Plasenta \\
\hline
\end{tabular}

B. Design

Dalam perancangan ini penulis menggunakan tool UML (Unifiel modelling language) sebagai rancangan dari sebuah model sistem akan dibangun mencakup perancangan [8] :

1. Perancangan Proses

\section{a. Usecase Scenario}

Pada tahap ini peneliti akan membuat scenario utama dalam perancangan dua user yaitu ibu hamil dan operator, yang dijelaskan melalui scenario sebagai alur kerja sistem.

\section{b. Use Case diagram}

Mendeskripsikan sebuah interaksi anatara satu atau lebih aktor dengan sistem informasi yang akan dibuat. Dapat dikatakan usecase dapat digunakan mengetahui fungsi apa saja yang ada didalam sistem informasi dan siapa saja yang berhak menggunakan fungsi tersebut.

c. Activity Diagram

Activity Diagaram yaitu suatu diagram yang menggambarkan konsep aliran data atau kontrol, aksi tersetruktur serta dirancang dengan baik dalam suatu sistem.

\section{d. Sequence Diagram}

Sequence diagram adalah sebuah diagram yang menggambarkan kolaborasi dari objek-objek yang saling berinteraksi antar elemen dari suatu class.

e. Class Diagram

Class diagram sebuah diagram yang menunjukan hubungan antar class yang didalamnya terdapat atribut dan fungsi dari suatu objek.

2. Perancangan Interface

Rancangan Interface merupakan rancangan yang akan digunakan pada sistem yang akan dibuat sepert: Halaman utama masing-masing user, halaman diagnosa, halaman konsultasi, halaman nilai Dempster Shafer, halaman informasi penyakit, dan halaman gejala, halaman riwayat, dan halaman login. 


\section{Implementation}

Tahap implementasi merupakan tahap meletakan sistem supaya siap dioperasikan. Software yang digunakan adalah XAMPP yang meliputi: apache sebagai web server, PHP sebagai bahasa pemograman, dan MySQL sebagai database-nya. Selain itu juga menggunakan sistem berbasis web sebagai penerapan suatu sistem diagnosa gangguan kehamilan pada ibu hamil dengan menggunakan metode Dempster Shafer.

\section{HaSil Dan PEMbahasan}

A. Analisis Sistem Yang Berjalan

Sistem yang berjalan pelayanan pasien ibu hamil yang berada di Rumah Sakit AMC Kota Metro sistem pemeriksaan ibu hamil mempunyai tahapan diantaranya sebagai berikut:

1. Pasien datang ke bagian Administrasi rumah sakit untuk memberikan buku "Panduan Cerdas Pemeriksaan Ibu Hamil" kepada bagian administrasi rumah sakit .Jika pasien baru mendaftarkan diri maka diminta untuk melampirkan atau fotocopy kartu keluarga dan kartu tanda penduduk. Untuk mendapatkan buku "Panduan Cerdas Pemeriksaan Ibu Hamil”.
2. Bagian administrasi rumah sakit memberikan pasien tersebut nomer antrian ke pasien selanjutnya menyerahkan buku "Panduan Cerdas Pemeriksaan Ibu Hamil" kepada administrasi rumah sakit .

3. Bagian administrasi rumah sakit mencocokkan nomer buku "Panduan Cerdas Pemeriksaan Ibu Hamil" dengan Useradmin yang sesuai dengan buku "Panduan Cerdas Pemeriksaan Ibu Hamil" dan menyerahkan pasien kepada dokter .

4. Dokter akan mencatat hasil pemeriksaan keadaan kandungan ibu hamil, kemudian memberikan saran jika termasuk pada fase I (satu) dan apa bila kondisi ibu hamil mengalami pada fase II (dua) maka dokter memberi resep obat yang tepat untuk ibu dan kandungannya.

5. Bila hasil pemeriksaan menunjukkan bahwa pasien terdapat gangguan kehamilan pada fase III (tiga), maka dokter akan membuatkan surat rujukan ke ruangan opname (rawat inap).

6. Bagian administrasi rumah sakit akan membuat catatan laporan buku "Panduan Cerdas Pemeriksaan Ibu Hamil” serta 
menghitung biaya konsultasi tentang kehamilan dan konsultasi kehamilan setiap bulannya akan diserahkan kepada dokter jika suatu waktu diperlukan.

B. Analisis Sistem Yang Diusulkan Perancangan yang penulis usulkan yaitu menggunakan metode berorientasi objek meliputi: Scenario diagram, Use case diagram, Activity diagram dan Squence diagram. Dalam sistem yang diusulkan meliputi perancangan program dan struktur, Berikut penjelasan Sistem yang diusulkan yang akan diterapkan pada RS AMC Kota Metro meliputi Pembuatan hak akses pasien dan admin :

1. User merupakan seluruh ibu hamil pengguna sistem, mempunyai kewenangan melihat hasil diagnosa tentang penyakit gangguan kehamilan dengan melakukan konsultasi dan mendapatkan solusi dari penerapan metode Dempster Shafer.

2. Admin mempunyai kewenangan penuh terhadap sistem. Sistem pakar diagnosa gangguan kehamilan pada ibu hamil dapat melihat dan mengubah semua data sistem, dan dapat memperbaiki aturan kesalahan yang terjadi dalam sistem. Admin yang akan mengolah data diagnosa gangguan kehamilan pada ibu hamil menggunakan metode Dempster Shafer. Admin juga yang memasukkan data basis pengetahuan gangguan kehamilan pada ibu hamil dan gejala serta penilaian sehingga sesuai dengan aturan metode Dempster Shafer. Admin dapat menambah,mengurangi, melihat riwayat konsultasi yang ada.

\section{Penerapan Metode Dempster Shafer}

1. Aturan dan pembobotan nilai plausibility dan nilai belief [9].

a. Belief (Bel) adalah ukuran kekuatan evidenc dalam mendukung suatu himpunan proposisi [10]. Jika bernilai 0 maka mengindikasikan bahwa tidak ada evidence, dan jika bernilai 1 menunjukkan adanya kepastian.

b. Plausibility (Pl) dinotasikan sebagai : $\mathrm{Pl}(\mathrm{s})=1-\operatorname{Bel}(\ulcorner\mathrm{s})$ 
Aturan dan nilai terbobot anatara gejala ibu dapat dilihat pada Tabel 3.

dan penyakit gangguan kehamilan pada

\section{Tabel 3. Aturan dan nilai terbobot}

\begin{tabular}{|c|c|c|c|c|c|c|c|}
\hline \multirow[b]{2}{*}{$\begin{array}{l}\text { Kode } \\
\text { Gejala }\end{array}$} & \multirow[b]{2}{*}{ Nama Gejala } & \multirow[b]{2}{*}{$\begin{array}{c}\text { Nilai } \\
\text { Densitas }\end{array}$} & \multicolumn{5}{|c|}{ Nilai Plausibility Penyakit Gangguan Kehamilan } \\
\hline & & & Ektopik & Hidatidosa & $\begin{array}{l}\text { Post } \\
\text { term }\end{array}$ & $\begin{array}{c}\text { Plasenta } \\
\text { Previa }\end{array}$ & $\begin{array}{c}\text { Solutio } \\
\text { Plasenta }\end{array}$ \\
\hline G1 & $\begin{array}{l}\text { Nyeri pada puncak bahu } \\
\text { dan sisi leher }\end{array}$ & 0,72 & 0,28 & 0 & 0 & 0 & 0 \\
\hline G2 & $\begin{array}{l}\text { Pendaharahan pada } \\
\text { vagina sedikit warna } \\
\text { coklat gelap }\end{array}$ & 0,60 & 0,40 & 0 & 0 & 0 & 0 \\
\hline G3 & $\begin{array}{l}\text { Kepala pusing kunang- } \\
\text { kunang dan denyut nadi } \\
\text { meningkat }\end{array}$ & 0,53 & 0,47 & 0 & 0 & 0 & 0 \\
\hline G4 & $\begin{array}{l}\text { Suhu tubuh panas } \\
\text { meningkat } 38^{\circ} \mathrm{C}\end{array}$ & 0,83 & 0,17 & 0 & 0 & 0 & 0 \\
\hline G5 & $\begin{array}{l}\text { Pendarahan merupakan } \\
\text { gejala utama }\end{array}$ & 0,74 & 0 & 0,26 & 0 & 0 & 0 \\
\hline G6 & $\begin{array}{l}\text { Mual muntah seperti } \\
\text { kehamilan biasa } \\
\text { semeseter } \geq 1 \text { dengan } \\
\text { semester } \leq 6 \text { hanya derajat } \\
\text { keluhan lebih dari yang } \\
\text { biasa }\end{array}$ & 0,62 & 0 & 0,38 & 0 & 0 & 0 \\
\hline G7 & $\begin{array}{l}\text { Perkembangan kehamilan } \\
\text { semester } \geq 6 \text { lebih pesat } \\
\text { dari kehamilan biasa }\end{array}$ & 0,83 & 0 & 0,17 & 0 & 0 & 0 \\
\hline G8 & $\begin{array}{l}\text { Pendarahan tanpa alasan } \\
\text { atau tanpa rasa nyeri. }\end{array}$ & 0,75 & 0 & 0 & 0 & 0,25 & 0 \\
\hline G9 & $\begin{array}{l}\text { Pendarahan dapat terjadi } \\
\text { selagi penderita tidur atau } \\
\text { bekerja biasa }\end{array}$ & 0,85 & 0 & 0 & 0 & 0,15 & 0 \\
\hline G10 & $\begin{array}{l}\text { Terjadi pembukaan } \\
\text { saluran air ketuban }\end{array}$ & 0,78 & 0 & 0 & 0,22 & 0 & 0 \\
\hline G11 & Gerakan janin yang jarang & 0,81 & 0 & 0 & 0,19 & 0 & 0 \\
\hline G12 & Sakit perut terus menerus & 0,80 & 0 & 0 & 0 & 0 & 0,20 \\
\hline G13 & $\begin{array}{l}\text { Otot pada kandung } \\
\text { kemihg anda terasa } \\
\text { tegang }\end{array}$ & 0,65 & 0 & 0 & 0 & 0 & 0,35 \\
\hline G14 & $\begin{array}{l}\text { Detak jantung janin tidak } \\
\text { terdengar lagi }\end{array}$ & 0,70 & 0 & 0 & 0 & 0 & 0,30 \\
\hline G15 & Pendarahan dan shok & 0,40 & 0 & 0 & 0 & 0 & 0,60 \\
\hline
\end{tabular}

Sumber: dr. Ellysawati Shinta, SpoG. Selaku dokter praktik RS AMC Kota Metro.

2. Contoh studi kasus yang diberikan berupa data rekam medik : dr.Ellysawati Shinta,SpoG.

a) Pada kasus pertama yakni seorang ibu hamil yang bernama Martina binti Waluyo. bertempat tinggal di Jl.
Raya Pasar $\mathrm{Tj}$. Harapan, Seputih Banyak, Kabupaten Lampung Tengah, Lampung. Memliki beberapa keluhan/gejala yang dirasakan pada masa kehamilan. Otot pada kandung kemih anda terasa 
tegang, Sakit perut terus menerus, dan Pendarahan merupakan gejala utama. Tabel 4 menjelaskan nilai densitas dan plausibility pada kasus I.

Tabel 4. Nilai densitas dan nilai plausibility kasus I

\begin{tabular}{|c|c|c|c|c|}
\hline $\begin{array}{l}\text { Kode } \\
\text { Geiala }\end{array}$ & Gejala & Pesayakit & Densitas & Plumabiling \\
\hline GS & 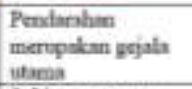 & Halastidoaa & 0,74 & 0.26 \\
\hline G12 & $\begin{array}{l}\text { Sakit penut terus } \\
\text { mavervi }\end{array}$ & $\begin{array}{l}\text { Sulutio } \\
\text { Pluseatry }\end{array}$ & 0,80 & 0.20 \\
\hline G13 & 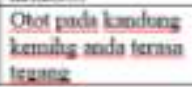 & $\begin{array}{l}\text { Soluno } \\
\text { Plitumeta }\end{array}$ & 0,65 & 0.5 \\
\hline
\end{tabular}

Ilustrasi nilai keyakinan pada setiap gejala akan dijelaskan pada Tabel 5, Tabel 6, Tabel 7, Tabel 8, Tabel 9 dan Tabel 10.

1) Gejala 5 : Pendarahan merupakan gejala utama

Langkah Pertama hitung nilai belief dan plausibility dari gejala [11] Pendarahan merupakan gejala utama (G5)

$\mathrm{M}_{1}(\mathrm{G} 5)=0,74$
$\mathrm{M}_{1}\{\Theta\}=1-\mathrm{M}_{1}(\mathrm{G} 13)=1-0,74=$
0,26

2) Gejala $12:$ Sakit perut terus menerus Apabila diketahui adanya gejala baru, yaitu Sakit perut terus menerus (G12), maka nilai keyakinannya

$\mathrm{M}_{2}(\mathrm{G} 12)=0,80$

$\mathrm{M}_{2}\{\Theta\}=1-\mathrm{M}_{2}(\mathrm{G} 12)=1-0,80=$ 0,20
Tabel 5. Ilustrasi nilai keyakinan gejala 2

\begin{tabular}{|l|c|c|}
\hline $\mathrm{M}_{1}$ & $\mathrm{M}_{2}(\mathrm{G} 12)=0,80$ & $\mathrm{M}_{2}(\Theta)=0,20$ \\
\hline $\mathrm{M}_{1}(\mathrm{G} 5)=0,74$ & 0,592 & 0,0962 \\
\hline $\mathrm{M}_{1}(\Theta)=0,26$ & 0,208 & 0,052 \\
\hline
\end{tabular}

Selanjutnya menghitung tingkat keyakinan (m) combine dengan rumus (3), maka

$$
\begin{aligned}
M_{3} & =\frac{(0,80 \times 0,74)+(0,80 \times 0,26)+(0,26 \times 0,20)}{1-0} \\
& =0,852 \\
M_{3} & \{\Theta\}=\frac{0,26+0,20}{1-0}=0,46
\end{aligned}
$$

3) Gejala 13 : Otot pada kandung kemih anda terasa tegang

$$
\begin{aligned}
& \mathrm{M}_{4}(\mathrm{G} 5)=0,65 \\
& \mathrm{M}_{4}\{\Theta\}=1-\mathrm{M}_{4}(\mathrm{G} 5)=1-0,65= \\
& 0,35
\end{aligned}
$$

\section{Tabel 6. Ilustrasi nilai keyakinan} gejala 3

\begin{tabular}{|l|c|c|}
\hline $\mathrm{M}_{3}$ & $\mathrm{M}_{4}(\mathrm{G} 12)=0,65$ & $\mathrm{M}_{4}(\boldsymbol{\theta})=0,35$ \\
\hline $\mathrm{M}_{\mathrm{S}}(\mathrm{G} 12)=0,852$ & 0,5538 & 0,2982 \\
\hline $\mathrm{M}_{\mathrm{s}(\Theta)=0,46}$ & 0,299 & 0,161 \\
\hline
\end{tabular}

Selanjutnya menghitung tingkat keyakinan (m) baru.

$$
\begin{aligned}
M_{5} & =\frac{(0,65 \times 0,87)+(0,65 \times 0,46)}{1-0} \\
& =0,8528
\end{aligned}
$$

Maka nilai akhir $=$ Densitas baru $\times 100 \%$ $M_{3,5} \times 100 \%=0,8528 \times 100 \%=85,28 \%$, untuk $\mathrm{M}_{3,5}\{\Theta\}$ kenapa tidak dihitung karena apa bila tidak ada gejala setelahnya. Adapun hasil dari pengujian metode dempster shafer dengan pasien. Mendiagnosa berdasarkan IF Pendarahan 
merupakan gejala utama AND Sakit perut terus menerus AND Otot pada kandung kemih anda terasa tegang THEN Solutio Plasenta dan Hidatidosa. Dengan nilai 85,28\% maka gangguan kehamilan ibu Martina binti Waluyo mengalami gangguan kehamilan Solutio Plasenta dan Hidatidosa.

b) Pada contoh kasus kedua seorang ibu hamil yang bernama Nining Asatun binti Karji. Bertempat tinggal di J1. AH Nasution, Yosodadi, Kec. Metro Timur, Kota Metro, Lampung. Memliki beberapa keluhan/gejala yang dirasakan pada masa kehamilan. Pendarahan tanpa alasan atau tanpa rasa nyeri, Pendarahan dapat terjadi selagi penderita tidur atau bekerja biasa, Pendarahan dan shok, dan Pendaharahan pada vagina sedikit warna coklat gelap.

Tabel 7. Nilai densitas dan nilai plausibility kasus II

\begin{tabular}{|c|c|c|c|c|}
\hline $\begin{array}{l}\text { Kode } \\
\text { Gejala }\end{array}$ & Gejala & Penyakit & Densitas & Plausability \\
\hline G2 & $\begin{array}{l}\text { Pendaharahan pada } \\
\text { vagina sedilkit warma } \\
\text { coldat gelap. }\end{array}$ & Ehtopok & 0,60 & 0,40 \\
\hline G8 & $\begin{array}{l}\text { Pendanihan tanpa } \\
\text { alasan atan tanpa rasa } \\
\text { byeri }\end{array}$ & $\begin{array}{l}\text { Plasenta } \\
\text { Previa }\end{array}$ & 0,75 & 0.25 \\
\hline G9 & $\begin{array}{l}\text { Pendarahan dapat } \\
\text { terjadi selagi } \\
\text { penderita tidua atau } \\
\text { bekerja biasa }\end{array}$ & $\begin{array}{c}\text { Plasenta } \\
\text { Previa }\end{array}$ & 0,85 & 0.15 \\
\hline G15 & Pendanahan dan shok & $\begin{array}{l}\text { Solutio } \\
\text { Plasenta }\end{array}$ & 0,40 & 0,60 \\
\hline
\end{tabular}

1) Gejala 2 : Pendaharahan pada vagina sedikit warna coklat gelap
Langkah Pertama hitung nilai belief dan plausibility dari gejala Pendaharahan sedikit warna coklat gelap (G2)

$\mathrm{M}_{1}(\mathrm{G} 2)=0,60$

$\mathrm{M}_{1}\{\Theta\}=1-\mathrm{M}_{1}(\mathrm{G} 2)=1-0,60=0,40$

2) Gejala 8 : Pendarahan tanpa alasan atau tanpa rasa nyeri, yaitu Pendarahan tanpa alasan atau tanpa rasa nyeri (G8), maka nilai keyakinannya

$\mathrm{M}_{2}(\mathrm{G} 8)=0,75$

$\mathrm{M}_{2}\{\Theta\}=1-\mathrm{M}_{2}(\mathrm{G} 8)=1-0,75=$ 0,25

Tabel 8. Ilustrasi nilai keyakinan gejala 2

\begin{tabular}{|l|c|c|}
\hline $\mathrm{M}_{1}$ & $\mathrm{M}_{2}(\mathrm{G})=0,75$ & $\mathrm{M}_{2}(\Theta)=0,25$ \\
\hline $\mathrm{M}_{1}(\mathrm{G})=0,60$ & 0,45 & 0,15 \\
\hline $\mathrm{M}_{1}(\Theta)=0,40$ & 0,3 & 0,1 \\
\hline
\end{tabular}

Selanjutnya menghitung tingkat keyakinan (m) combine dengan rumus (3), maka

$$
\begin{aligned}
& M_{3}=\frac{(0,55 \times 0,60)+(0,55 \times 0,45)+(0,45 \times 0,25)}{1-0} \\
& =0,85 \\
& M_{3}\{\Theta\}=\frac{0,45+0,25}{1-0}=0,65
\end{aligned}
$$

3) Gejala 9 : Pendarahan dapat terjadi selagi penderita tidur atau bekerja biasa (G9), maka nilai keyakinannya $\mathrm{M}_{4}(\mathrm{G} 9)=0,85$ $\mathrm{M}_{4}\{\Theta\}=1-\mathrm{M}_{2}(\mathrm{G} 15)=1-0,85=0,15$

Tabel 9. Ilustrasi nilai keyakinan gejala 3

\begin{tabular}{|l|c|c|}
\hline $\mathrm{M}_{3}$ & $\mathrm{M}_{4}(\mathrm{G} 9)=0,85$ & $\mathrm{M}_{5}(\Theta)=0,15$ \\
\hline $\mathrm{M}_{3}(\mathrm{G} 8)=0,85$ & 0,7225 & 0,1275 \\
\hline $\mathrm{M}_{3}(\Theta)=0,65$ & 0,5525 & 0,0975 \\
\hline
\end{tabular}


Selanjutnya menghitung tingkat keyakinan (m) combine dengan rumus (3), maka

$\mathrm{M}_{5}=\frac{(0,85 \times 0,85)+(0,85 \times 0,65)+(0,65 \times 0,15)}{1-0}$ $=1,3725$

$\mathrm{M}_{5}\{\Theta\}=\underline{0,65+0,15}=0,80$

$$
1-0
$$

4) Gejala 15 : Pendarahan dan shok, yaitu Pendaharahan sedikit warna coklat gelap (G15), maka nilai keyakinannya

$$
\begin{aligned}
& \mathrm{M}_{6}(\mathrm{G} 2)=0,40 \\
& \mathrm{M}_{6}\{\Theta\}=1-\mathrm{M}_{2}(\mathrm{G} 2)=1-0,40=0,60
\end{aligned}
$$

\section{Tabel 10. Ilustrasi nilai} keyakinan gejala 4

\begin{tabular}{|l|c|c|}
\hline M5 & $\mathrm{M}_{6}(\mathrm{G} 15)=0,40$ & $\mathrm{M}_{6}(\Theta)=0,60$ \\
\hline $\mathrm{M}_{5}(\mathrm{G} 9)=1,3725$ & 0,549 & 0,8235 \\
\hline $\mathrm{M}_{5}(\Theta)=0,80$ & 0,32 & 0,48 \\
\hline
\end{tabular}

Selanjutnya menghitung tingkat keyakinan (m) baru.

$$
\mathrm{M}_{7}=\frac{(0,40 \times 1,3725)+(0,40 \times 0,80)}{1-0}=0,869
$$

Maka nilai akhir $=$ Densitas baru $\times 100 \%$ $M_{7} \times 100 \%=0,869 \times 100 \%=86,9 \%$, untuk $M_{3}\{\Theta\}$ kenapa tidak dihitung karena apa bila tidak ada gejala setelahnya. Adapun hasil dari pengujian metode dempster shafer dengan pasien. Mendiagnosa berdasarkan IF
Pendaharahan pada vagina sedikit warna coklat gelap AND Pendarahan tanpa alasan atau tanpa rasa nyeri AND Pendarahan dapat terjadi selagi penderita tidur atau bekerja biasa AND Pendarahan dan shok. Apabila diketahui adanya gejala THEN Plasenta Previa. Dengan nilai $86,9 \%$ maka gangguan kehamilan ibu Nining Asatun binti Karji mengalami gangguan kehamilan Solutio Plasenta.

\section{IV.SIMPULAN}

Sistem diagnosa gangguan kehamilan memiliki dua user yang terbagi menjadi 2 hak akses yakni ibu hamil dan operator aplikasi. Fitur yang disajikan diaplikasi tersebut ibu hamil dapat berkonsultasi ke sistem selanjutnya ibu hamil dapat melihat hasil konsultasi dan menunggu hasil rekomendasi yang diberikan oleh sistem, sedangkan operator dapat hanya bisa memeasukan data gejala berikut dengan nilai densitas (nilai pakar) serta nilai pseubilitas (nilai kepercayaan) berikut dengan rekomendasi untuk ibu hamil yang mengalami gangguan kehamilan. Sistem pakar ini dapat digunakan untuk mendiagnosa ganguan kehamilan pada ibu dengan tingkat presentase sistem pakar sebesar 86,9\%, sehingga dapat digunakan oleh ibu hamil dan membantu Dokter untuk mendiagnosa dini gangguan kehamilan. 


\section{PENELITIAN LANJUTAN}

Sistem pakar diagnosa gangguan kehamilan mampu dikembangkan lebih lanjut untuk menggunakan metode lain dan diharapkan aplikasi sistem pakar ini dikembangkan menjadi aplikasi multiuser dengan basis mobile sehingga fungsi dan kegunaannya dapat dipakai secara luas oleh banyak orang dimanapun dan kapanpun sesuai dengan Operating System pada mobile tersebut

\section{DAFTAR PUSTAKA}

[1] S. M. Anisa, "PENERAPAN METODE FORWARD

CHAINING

UNTUK

MENDIAGNOSA GANGGUAN

PADA KEHAMILAN IBU," Int.

Res. Big Data Comput. Technol., vol. 4, p. 172, 2020.

[2] S. Muharni and S. Andriyanto, "Sistem Diagnosa Penyakit Jantung Berbasis Case Based Reasoning (CBR)," in Prosiding Seminar Nasional Darmajaya, 2021, vol. 1, pp. 1-11.

[3] A. Fatmawati and F. Marisa, "SISTEM PENDUKUNG KEPUTUSAN DIAGNOSIS GANGGUAN KEHAMILAN MENGGUNAKAN METODE FTOPSIS BERBASIS WEB," Din. Dotcom J. Pengemb. Manaj.
Inform. dan Komput., 2019.

[4] S. Muharni, S. Kom, and M. TI, Analisa dan Perancangan Sistem Informasi: Bintang Pustaka. Yogyakarta: Bintang Pustaka Madani, 2021.

[5] T. Puspitasari, B. Susilo, and F. F. Coastera, "Implementasi Metode Dempster-Shafer Dalam Sistem Pakar Diagnosa Anak Tunagrahita Berbasis Web," Rekursif $J$. Inform., vol. 4, no. 1, 2016.

[6] S. Kusumadewi, "Pengertian Sistem Pakar," Yogyakarta Graha Ilmu, 2003.

T. Limbong and A. Rikki, "IMPLEMENTATION OF FORWARD INFERENCE REASONING IMPLEMENTING THE DEMPSTER-SHAFER METHOD FOR DIAGNOSIS OF LUNG DISEASE SYMPTOMS," INFOKUM, vol. 9, no. 2, June, pp. 106-118, 2021.

[8] A. Altaher, "Unified Modelling Language (UML) Effect on the Total Cost of Ownership (TCO) for a Software Development," Iraqi J. Sci., pp. 207-209, 2021.

[9] F. Voorbraak, “A computationally efficient approximation of Dempster-Shafer theory," Int. J. Man. Mach. Stud., vol. 30, no. 5, 
pp. 525-536, 1989.

[10] E. F. Rahayu, "COMPARATIVE

ANALYSIS EXPERT SYSTEM

OF CERTAINTY FACTOR

METHOD WITH DEMPSTER

SHAFER METHOD BY USING

OPEN DECISION MAKER

TOOL FOR TODDLER AT

VACCINE HOUSE," UG J., vol.

14, no. 4, 2021.

[11] L. Herawati and A. Eviyanti, “Gynecological Disease Diagnosis Expert System Using the WebBased Dempster Shafer Method," Procedia Eng. Life Sci., vol. 1, no. 2, 2021.

[12] Liandi, O., \& Fitria, F. (2019). Evaluasi Tata Kelola Framework COBIT 5 pada Dinas Kependudukan dan Pencatatan Sipil. POSITIF: Jurnal Sistem dan Teknologi Informasi, 5(2), 111115.

[13] Wibowo, H., \& Indriyani, F. (2018, October). K-Nearest Neighbor Method For Monitoring Of Production And Preservation Information (Treatment) Of Rubber Tree Plant. In International Conference on Information Technology and Business (ICITB) (pp. 29-44). 